\title{
Quantitative review of ruminal and total tract digestion of mixed diet organic matter and carbohydrates
}

\author{
H Archimède *, D Sauvant, P Schmidely \\ Station de nutrition et d'alimentation, Inra, Ina-PG, 16, rue Claude-Bernard, \\ 75231 Paris cedex 05, France
}

(Received 19 March 1996; accepted 20 November 1996)

\begin{abstract}
Summary - The mean response and main factors of variation (level of concentrate, nature of carbohydrate in the concentrate and level of intake) for organic matter, cell wall material, starch digestion and microbial synthesis in the gastrointestinal tract of ruminants were quantitatively reviewed using a data base involving 157 papers. The ruminal digestion (mean \pm SE\%) of organic matter, cell wall material, and starch were 45.2 $\pm 11.2(n=553), 47.7 \pm 17.7(n=348)$, and $74.1 \pm 16.2(n=140)$, respectively and the proportion of each component digested in the rumen in relation to total tract digestibility was $64.7 \pm 12.3,78.8 \pm 18.5$ and $80.5 \pm 16.3$, respectively. The efficiency of microbial synthesis ( $\mathrm{g}$ of microbial protein $/ \mathrm{kg}$ of organic matter truly fermented in the rumen) and the proportion of microbial nitrogen in the total amount of nitrogen leaving the stomachs $(\%)$ were, $23.6 \pm 9.3(n=$ $320)$ and $55.1 \pm 16.5(n=289)$, respectively. The ruminal digestion of organic matter increased by 2 points for every 10 percent increase in concentrate incorporation. The ruminal digestion of cell wall material was maximal when the concentrate incorporation in the diet was $30 \%$. When the ruminal digestion of cell wall decreased, the substitution of ruminal digestion by intestinal digestion was partial $(10 \%)$. The efficiency of microbial synthesis was optimal when the level of concentrate incorporation was $40 \%$. The nature of the carbohydrates in the concentrates had a significant effect on the efficiency of the microbial synthesis, which was higher $(+6.6 \mathrm{~g}$ of nitrogen $/ \mathrm{kg}$ of fermentable organic matter in the rumen) with slowly degradable starch (SS) or digestible fiber (DF) than with rapidly degradable starch (RS). Moreover, the mean depression of cellulolysis in the rumen was higher with RS ( -13 points) comparatively to SS ( -7 points) or DF ( -5 points).
\end{abstract}

ruminal digestion / total tract digestion / microbial synthesis

* Correspondence and reprints.

Present address: Inra, station de recherches zootechniques, Prise d'Eau, 91170 Petit-Bourg, Guadeloupe, French West Indies.

Tel: (590) 2559 33; fax: (590) 2559 36; e-mail: archi@antilles.inra.fr 


\begin{abstract}
Résumé - Étude bibliographique quantitative de la digestion ruminale et totale de la matière organique et des carbohydrates. Une étude quantitative de la bibliographie (157 publications) a été réalisée afin d'étudier la loi de réponse et les principaux facteurs de variations (niveau et nature des glucides des concentrés, niveau d'ingestion), de la digestion de la matière organique, des parois, de l'amidon et de la synthèse microbienne dans le tube digestif des ruminants. La digestion ruminale (moyenne \pm écart type \%) de la matière organique, des parois, et de l'amidon sont de 45,2 $\pm 11,2$ $(n=553), 47,0+17,7(n=348)$, et 74,1 $\pm 16,2(n=140)$ respectivement. Selon le même ordre, les rapports entre la digestion ruminale et la digestion totale sont de $64,7 \pm 12,3,78,8 \pm 18,5$ et $80,5 \pm 16,3$ respectivement. L'efficacité de la synthèse microbienne ( $\mathrm{g}$ d'azote microbien $/ \mathrm{kg}$ de matière organique réellement fermentée dans le rumen) est de 23,6 $9,3(n=320)$. La quantité d'azote microbien rapporté à l'azote total atteignant le duodénum (\%) est de 55,1 $\pm 16,6(n=289)$. La digestion ruminale de la matière organique augmente de deux points pour dix points de concentré supplémentaire dans la ration. La digestion ruminale des parois est maximale avec environ $30 \%$ de concentré dans la ration. La substitution de la digestion ruminale des parois par une digestion intestinale n'est que partielle (environ $10 \%$ ). L'efficacité de la synthèse microbienne est optimale avec environ $40 \%$ d'incorporation de concentré dans la ration. La nature des glucides des concentrés a un effet significatif sur l'efficacité de la synthèse microbienne qui est plus élevée $(+6,6 \mathrm{~g}$ d'azote microbien $/ \mathrm{kg}$ de matière organique réellement fermentée dans le rumen) avec l'amidon lentement dégradable et les parois dégradables comparativement à l'amidon rapidement dégradable. Par ailleurs, la diminution moyenne de cellulolyse ruminale, induite par le concentré amidon à dégradation rapide ( -13 points) est supérieure à celle du concentré amidon à dégradation lente ( -7 points) et à celle du concentré paroi ( -5 points).
\end{abstract}

digestion / rumen / tube digestif / synthèse microbienne

\section{ABBREVIATIONS USED}

ADF
ADL
C
CV
CW
DF
df
EMS
IDcw
NDF
OM
OMF

$\mathrm{RD}$

RDcw

RDom

RDst

RS

SD

SE

SS

TTD

TTDcw total tract digestibility of cell wall

TTDom total tract digestibility of organic matter

TTDst total tract digestibility of starch

\section{INTRODUCTION}

Improving the efficiency of ruminant diets is partly conditioned by a better understanding of the digestion sites for the various components of feed organic matter (OM). The partition of digestion of the non-structural and structural carbohydrates between the rumen and the intestine depends on the nature of the roughage or concentrate and their constituents, on the forage/concentrate ratio and, sometimes on the digestive interactions between the different diet ingredients or fractions. There are nutritional consequences due to variations in the digestive partitioning of the OM fractions. The starch that by-passes the rumen, is partly digested in the small intestine and can be absorbed as glucose, which could lead to a better utilisation of digestible nutrients (Nocek and Tamminga, 1991). The animal's energy supply (volatil fatty acids) and microbial protein is largely dependent on the OM fermented in the rumen.

The concentrate level and carbohydrate nature are known to be main factors 
involved in both the partitioning of the carbohydrate digestion in the ruminant gut and in the nature and the quantities of the products of digestion. The main objectives of this review were to point out the main effects relating to the level and nature of concentrate on the digestion of the organic matter and ingested carbohydrate, and the efficiency of the microbial synthesis.

\section{MATERIAL AND METHODS}

\section{Data base elaboration and coding}

The relevant literature was reviewed to form a data base. The major criterion for selecting a study was the simultaneous measurements of the total tract (TTD) and rumen digestibility (RD) of organic matter $(\mathrm{OM})$, or carbohydrates. When the neutral detergent fiber (NDF), acid detergent fiber (ADF) or cellulose (ADF-ADL) duodenal flow exceeded the faecal flow by $5 \%$ or more, probably because of inaccuracy in the measurements, experiments were excluded. Experiments with a significant effect of any feed additive (buffer, fat, antibiotics, etc) were not taken into account. The animals were divided into cattle and small ruminants (sheep and goat). Little studies dealt with goats. The roughage was divided into one of the following four groups: cereal silage (mainly maize silage), grass silage, hay or fresh grass, straw and raw by-products (hulls, etc). The nature of concentrates was taken into account, whenever possible, with the following classification: rapidly degradable starch (RS, barley, wheat and oat), slowly degradable starch (SS, corn and sorghum) and digestible fiber (DF). When the concentrate was a blend of several ingredients, it was included in the group with the ingredient having the highest level of incorporation, or the most fermentable carbohydrate if the two proportions were equal. Moreover, for starchy concentrates, treatments were grouped into whole grain or ground, flaked, rolled, cracked, and pelleted grains. NDF, ADF, and cellulose (ADF-ADL) digestibility data were pooled to give the same variable, cell wall material, (CW). However, they were also grouped according to the type of chemical analysis (NDF, ADF, cellulose). The duodenal flow estimation methods were classified in order to take into account methodological effects. Estimations resulting from re-entrant canulae were differentiated form T-piece type canulae. In this last group, the methods of labelling were divided into rare earths, chrome oxide, $\mathrm{Cr}$ mordanced on neutral detergent fiber, indigestible lignin as singleor double-marker method, indigestible cell wall material, fluid phase marker as single-marker methods, and acid insoluble ash as single- or double-marker method. Other groups were formed based on the ruminal balance of indigestible lignin and digesta fluxes.

The methods of measuring microbial flows were classified on the basis of the markers used: ribonucleic acid, diaminopimelic acid, D-Alanine, ${ }^{15} \mathrm{~N},{ }^{35} \mathrm{~S}$ and an indirect estimation using the undegradable nitrogen of the diet (nylon bag method). The choice of the microbial sample, source of variation (Yang, 1991; Broderick and Merchen, 1991) were not taken into account. The efficiency of microbial growth was expressed as $\mathrm{g}$ of nitrogen $/ \mathrm{kg}$ of organic matter truly fermented in the rumen. When the published values were per unit of apparently digested OM, they were transformed assuming a nitrogen content of microbial $\mathrm{OM}$ equal to $8 \%$ (mean literature value). When the results on dry matter were published alone, they were transformed into organic matter by using the following assumptions (Archimède, 1992) and mean values from the literature:

- organic matter intake $=0.88^{*}$ dry matter intake;

- rumen organic matter digestibility $=1.15^{*}$ rumen dry matter digestibility;

- total tract organic matter digestibility $=$ $1.05 *$ total tract dry matter digestibility.

Energy digestibility was calculated on the same basis as the dry matter digestibility.

Cattle and small ruminants (goats and sheep) were differentiated in the data base.

\section{Statistical analysis}

Analysis of variance was performed on each dependent variable with the general linear model procedure of SAS (1988) using two models:

(1) $\mathrm{Y}_{\mathrm{ij}}=\mu+\alpha_{\mathrm{i}}+\mathrm{a}_{1}{ }^{*} \mathrm{C}+\mathrm{a}_{2}{ }^{*} \mathrm{C}^{2}+\mathrm{b}^{* 1}+\mathrm{e}_{\mathrm{ij}}$ where $Y_{i j}$ is the digestibility data; $\alpha_{i}$ is the experimental effect; $a_{1}, a_{2}, b$ are the coefficients of regression; $\mathrm{C}$ is the concentrate level $(0 \leq \mathrm{C} \leq$ $1), 1\left(\mathrm{~g} / \mathrm{kg} \mathrm{LW}^{0.75}\right)$ is the level of ingestion of 
organic matter and $\mathrm{e}_{\mathrm{ij}}$ is the residual standard deviation used as error term.

(2) $\mathrm{Y}_{\mathrm{ijlmnop}}=\mu+\mathrm{F}_{\mathrm{j}}+\mathrm{C}_{\mathrm{k}}+\mathrm{T}_{1}+\mathrm{R}_{\mathrm{m}}+\mathrm{MF}_{\mathrm{n}}+$ $\mathrm{MM}_{\mathrm{o}}+\mathrm{a}_{1}{ }^{*} \mathrm{C}+\mathrm{a}_{2}{ }^{*} \mathrm{C}^{2}+\mathrm{b}^{*} \mathrm{l}+\mathrm{e}_{\mathrm{ijklmop}}$

where $Y_{\text {ijlmnop }}$ is the measured digestibility coefficient, $\mu$ is the overall mean, $F_{j}$ is the roughage class ( 4 degrees of freedom, $\mathrm{df}$ ), $\mathrm{C}_{\mathrm{k}}$ is the concentrate class ( $2 \mathrm{df}), \mathrm{T}_{1}$ is the technological treatment of concentrate $(4 \mathrm{df}), \mathrm{R}_{\mathrm{m}}$ is the animal class ( $1 \mathrm{df}), \mathrm{MF}_{\mathrm{n}}$ is the method used to estimate duodenal flows ( $12 \mathrm{df}), \mathrm{MM}_{\mathrm{o}}$ is the microbial marker $(5 \mathrm{df})$, and $\mathrm{e}_{\mathrm{ijklmop}}$ is the residual effect used as an estimation of the error term.

Analyses applied to total tract digestion prediction did not include the methods of duodenal flow estimation, and the microbial markers were taken into account only for the microbial studies.

The aim of model 1 was to test, within the experiments, the level of concentrate and OM intakes. Model 1 was used for experiments with at least two levels of concentrate. The aim of model 2 was to test other diet effects such as roughage and concentrate nature, concentrate treatment.

\section{RESULTS}

\section{General observations}

One hundred and fifty-seven references (experimental effect) were used to produce the data base. Approximately one half of these dealt with cattle studies, the others were from small ruminants, mainly sheep. Thirty-six references presented studies with at least two levels of the same concentrate. The partition of the observations between organic matter, cell wall-material, starch and diet digestibility is presented in table $\mathbf{I}$. The data partition between the types of forages or concentrates was unbalanced. The combinations between roughages and concentrates did not generate a normal distribution. Statistical analyses were performed with all the values in the data base. Discrepancies between the number of observations in table II compared to the number indicated in tables III to $\mathrm{V}$ result from a lack of information for all the tested effects.

Table I. Partition of the observations in the data base for the analysis of digestion of organic matter $(\mathrm{OM})$, cell wall (CW), starch; efficiency of microbial synthesis (EMS) and duodenal microbial flow.

\begin{tabular}{lcccccr}
\hline Concentrate & Component & \multicolumn{5}{c}{ Roughage } \\
\cline { 3 - 6 } & & $\begin{array}{c}\text { Cereal } \\
\text { silage }\end{array}$ & $\begin{array}{c}\text { Grass } \\
\text { silage }\end{array}$ & Hay & By-products & Straw \\
\hline \multirow{2}{*}{ None } & OM & & 20 & 132 & & \\
& CW & & 11 & 101 & & 21 \\
& Starch & & 2 & 3 & & 0 \\
\multirow{5}{*}{ Rapid starch } & EMS & & 18 & 35 & & 5 \\
& OM & 5 & 16 & 56 & 1 & 10 \\
& CW & 4 & 5 & 40 & 0 & 7 \\
Slow starch & Starch & 3 & 2 & 26 & 8 & 5 \\
& EMS & 5 & 10 & 39 & 0 & 6 \\
& OM & 96 & 1 & 103 & 54 & 34 \\
& CW & 14 & 1 & 64 & 25 & 16 \\
Digestible fiber & Starch & 22 & 0 & 35 & 37 & 2 \\
& EMS & 24 & 1 & 74 & 25 & 31 \\
& OM & 7 & 8 & 30 & 3 & 4 \\
& CW & 7 & 7 & 26 & 3 & 4 \\
& Starch & 5 & 0 & 6 & 0 & 0 \\
& EMS & 7 & 4 & 29 & 3 & 4 \\
\hline
\end{tabular}


Table II. Mean values of rumen and total tract digestion.

\begin{tabular}{|c|c|c|c|}
\hline Num & of observations & Mean & Standard error \\
\hline \multicolumn{4}{|l|}{ Organic matter $(\mathrm{OM})$} \\
\hline Ruminal digestion (\%) RDom & 553 & 45.16 & 11.02 \\
\hline Total tract digestion (\%) TTDom & 553 & 69.67 & 10.38 \\
\hline Post-ruminal digestion (\%) & 553 & 24.51 & 12.33 \\
\hline Digestible OM digested in rumen (\%) & 553 & 64.66 & 8.70 \\
\hline \multicolumn{4}{|l|}{ Cell wall $(\mathrm{CW})$} \\
\hline Ruminal digestion (\%) RDcw & 348 & 47.04 & 17.73 \\
\hline Total tract digestion (\%) TTDcw & 348 & 58.20 & 14.78 \\
\hline Post-ruminal digestion (\%) & 348 & 11.15 & 18.49 \\
\hline Digestible $\mathrm{CW}$ digested in rumen (\%) & 348 & 78.76 & 8.10 \\
\hline \multicolumn{4}{|l|}{ Starch (St) } \\
\hline Ruminal digestion (\%) RDst & 140 & 74.10 & 16.21 \\
\hline Total tract digestion (\%) TTDst & 140 & 93.24 & 7.57 \\
\hline Post-ruminal digestion $(\%)$ & 140 & 18.44 & 14.42 \\
\hline Digestible starch digested in rumen (\%) & 140 & 80.47 & 16.30 \\
\hline \multicolumn{4}{|l|}{ Microbial nitrogen } \\
\hline Efficiency of microbial synthesis $\left(\right.$ EMS) ${ }^{a}$ & 320 & 23.33 & 9.28 \\
\hline $\begin{array}{l}\text { Proportion of microbial nitrogen flowing in } \\
\text { duodenum }\left(\mathrm{g} / \mathrm{kg} \mathrm{LW}^{0.75}\right)\end{array}$ & 289 & 0.55 & 0.16 \\
\hline
\end{tabular}

$\mathrm{a}^{\mathrm{a}}(\mathrm{g} / \mathrm{kg}$ of $\mathrm{OM}$ truly digested in the rumen)

Total tract and ruminal organic matter digestion

The mean values of rumen and the total tract OM digestibility (RDom, TTDom) are presented in table II. Figure 1a shows the TTDom data from studies using at least two levels of concentrate. The TTDom increases with the concentrate level as illustrated by equation la (table III). The mean effect of $\mathrm{C}$ on TTDom is quadratic. Moreover, for the same level of concentrate, there are large variations in the TTDom from one trial to another as shown by figure $1 \mathrm{a}$. The TTDom decreases by 1 point for each $10 \mathrm{~g}$ increase in OMI $/ \mathrm{kg} \mathrm{LW}^{0.75}$.

The residual standard error of model 2 (table IV) is high, indicating that some important causative factors other than nature of roughage and concentrate, type of ani- mal, level of intake, have not been taken into account in this model.

The trials based on grass silage give the highest TTDom values, when compared with the hay or straw-based rations. The concentrates RS, SS and DF increase the TTDom by $6.6,8.8$ and 10.8 points respectively.

The RDom increases with the level of concentrate (fig $1 b$, equ $1 b$ ). For the same level of concentrate in the diet, the effect of the concentrate on the RDom represents $57 \%$ of the TTDom. The standard deviation of $\alpha_{i}$ indicates, when compared to TTDom (7.71 vs 5.51), a higher variation between trials. Model 2 (table V) shows that the method of duodenal flow determination is an important source of experimental variation $(24 \%)$. The interactions between the nature of roughage and concentrate, the nature of 
Table III. Effect of the level of concentrate (C) and organic matter ingested (OMI) on digestion. Equations of prediction of the total tract (TTD), ruminal (RD) and intestinal (ID) digestion of organic matter, cell wall and starch; prediction of efficiency of microbial synthesis (EMS) and the duodenal flows of microbial nitrogen (Nmic).

Organic matter (om)

1a) TTDom $=63.74( \pm 2.71)-0.10( \pm 0.026)^{*} \mathrm{OMI}-11.58( \pm 5.30)^{*} \mathrm{C}^{2}+34.38( \pm 4.94)^{*} \mathrm{C}$ (ref $=36, n=157, \mathrm{r}^{2}=0.87, \mathrm{rsd}=4.76, P=0.0001$ )

lb) $\mathrm{RDom}=43.10( \pm 3.28)-0.072( \pm 0.031) * \mathrm{OMI}+19.01( \pm 2.12) * \mathrm{C}$

(ref $=36, n=157, \mathrm{r}^{2}=0.77, \mathrm{rsd}=5.90, P=0.0001$ )

1c) IDom $=19.18( \pm 2.19)-10.17( \pm 4.31) * \mathrm{C}^{2}+13.77( \pm 3.94) * \mathrm{C}$

(ref $=36, n=157, \mathrm{r}^{2}=0.82, \mathrm{rsd}=3.94, P=0.0001$ )

Cell wall $(c w)$

2a) TTDcw $=55.76( \pm 4.15)-19.67( \pm 8.93) * \mathrm{C}^{2}+15.61( \pm 8.10)^{*} \mathrm{C}$

(ref $=30, n=132, \mathrm{r}^{2}=0.75, \mathrm{rsd}=7.42, P=0.0001$ )

2b) $\mathrm{RDcw}=48.8( \pm 5.87)-37.65( \pm 12.62) * \mathrm{C}^{2}+20.90( \pm 11.45) * \mathrm{C}$

(ref $=30, n=132, \mathrm{r}^{2}=0.64, \mathrm{rsd}=10.52, P=0.0001$ )

2c) IDcw $=5.47( \pm 3.66)+10.39( \pm 2.67) * \mathrm{C}$

(ref $\left.=30, n=132, \mathrm{r}^{2}=0.55, \mathrm{rsd}=6.92, P=0.0001\right)$

2d) $\mathrm{IDcw}=6.21( \pm 3.45)+13.03( \pm 2.88)^{*} \mathrm{C}^{2}$

(ref $=30, n=132, \mathrm{r}^{2}=0.57, \mathrm{rsd}=6.76, P=0.0001$ )

2e) $\mathrm{RDcw} / \mathrm{TTDcw}=88.72( \pm 7.28)-26.21( \pm 6.08) * \mathrm{C}^{2}$

(ref $\left.=30, n=132, \mathrm{r}^{2}=0.59, \mathrm{rsd}=14.28, P=0.0001\right)$

2f) $\mathrm{RDcw} / \mathrm{TTDcw}=89.97( \pm 7.75)-20.25( \pm 5.65)^{*} \mathrm{C}$

$\left(\mathrm{ref}=30, n=132, \mathrm{r}^{2}=0.57, \mathrm{rsd}=14.63, P=0.0001\right)$

Starch (st)

3a) RDst $=74.51( \pm 5.90)+11.82( \pm 4.04)^{*} \mathrm{C}^{2}$

(ref $\left.=15, n=61, \mathrm{r}^{2}=0.65, \mathrm{rsd}=0.10, P=0.0001\right)$

3b) $\mathrm{RDst}=68.20( \pm 7.10)+12.38( \pm 6.84)^{*} \mathrm{C}^{2}$

(slowly degradable starch, ref $=9, n=36, \mathrm{r}^{2}=0.55, \mathrm{rsd}=9.54, P=0.006$ )

3c) RDst/TTDst $=78.94( \pm 6.54)+7.92( \pm 4.47)^{*} \mathrm{C}^{2}$

$\left(\right.$ ref $\left.=15, n=61, \mathrm{r}^{2}=0.60, \mathrm{rsd}=10.13, P=0.0001\right)$

3d) IDst $=19.96( \pm 5.68)-7.45( \pm 3.88)^{*} \mathrm{C}^{2}$

(ref $\left.=15, n=61, \mathrm{r}^{2}=0.64, \mathrm{rsd}=8.79, P=0.0001\right)$

Efficiency of microbial synthesis

4a) EMS $=20.66( \pm 2.59)-23.33( \pm 5.86) * C^{2}+18.40( \pm 5.82) * \mathrm{C}$

(ref $=25, n=75, \mathrm{r}^{2}=0.84, \mathrm{rsd}=3.62, P=0.0001$ )

\section{Microbial nitrogen}

4b) Nmic $=0.22( \pm 0.22)+0.010( \pm 0.003) * \mathrm{OMI}-0.382( \pm 0.24)^{*} \mathrm{C}^{2}+0.386( \pm 0.251)^{*} \mathrm{C}$ (ref $\left.=25, n=75, \mathrm{r}^{2}=0.98, \mathrm{rsd}=0.14, P=0.0001\right)$

TTD, RD, ID are expressed in \%; EMS is expressed in $\mathrm{g}$ of nitrogen $/ \mathrm{kg}$ of organic matter truly digested in the rumen; $\mathrm{OMI}$ and Nmic are expressed in $\mathrm{g} / \mathrm{LW}^{0.75}$; $\mathrm{C}$ varies between 0 to 1 . 


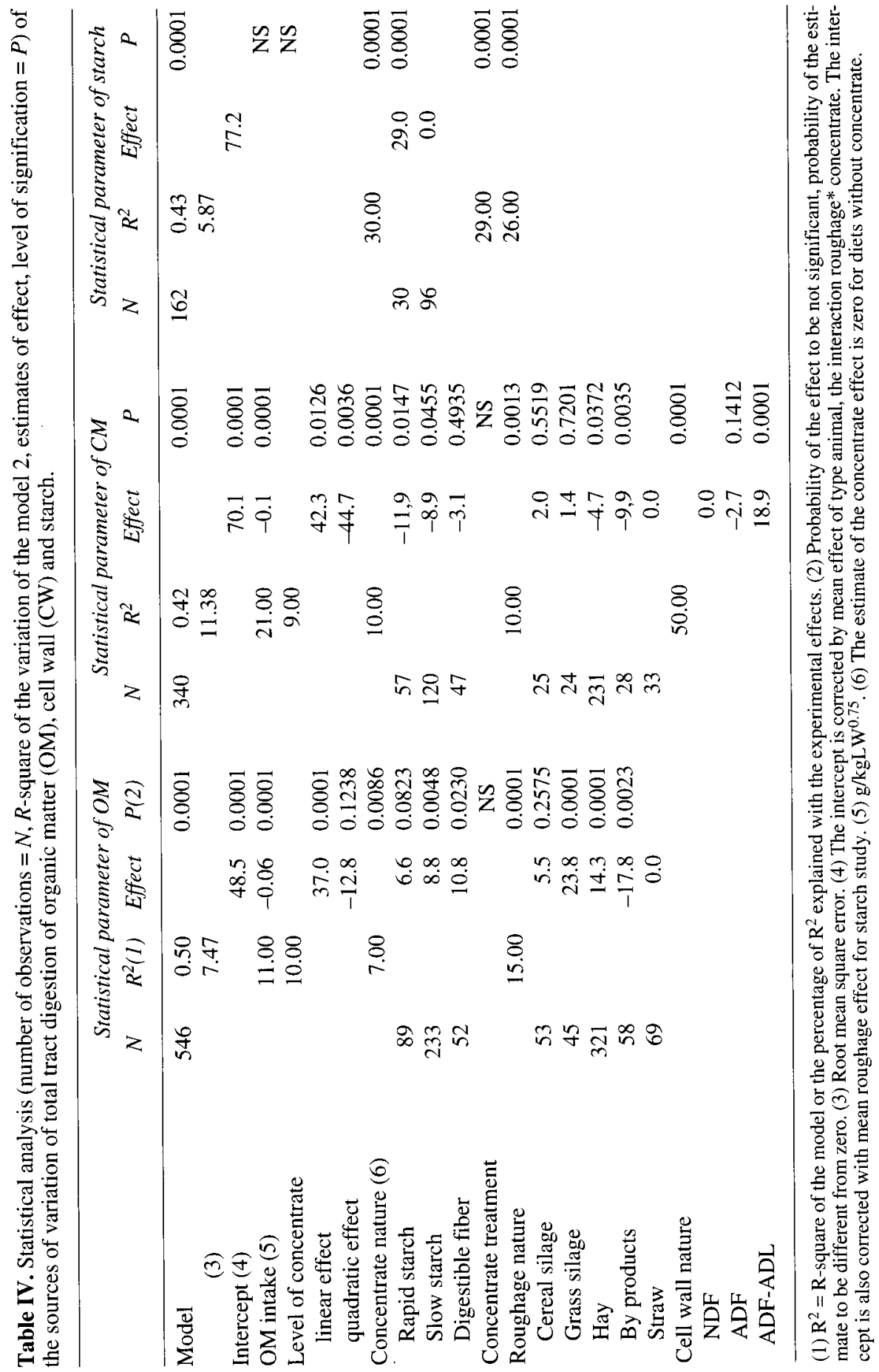




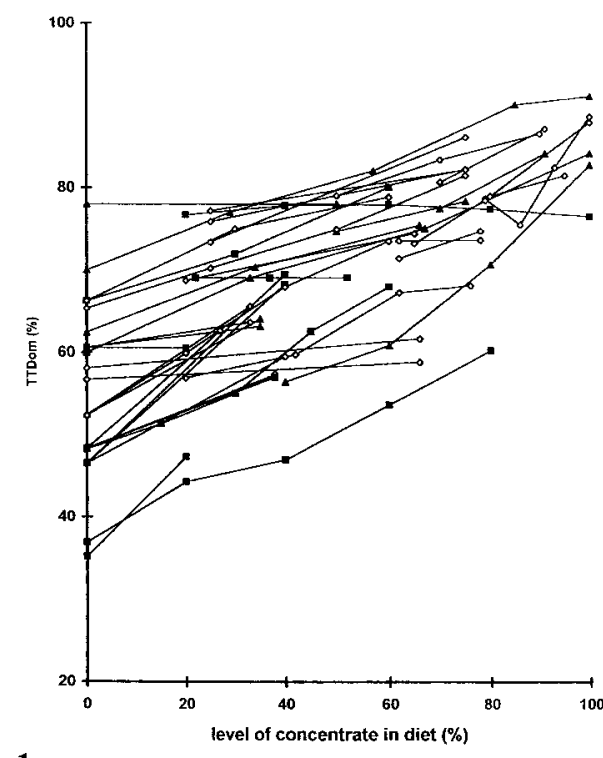

1a

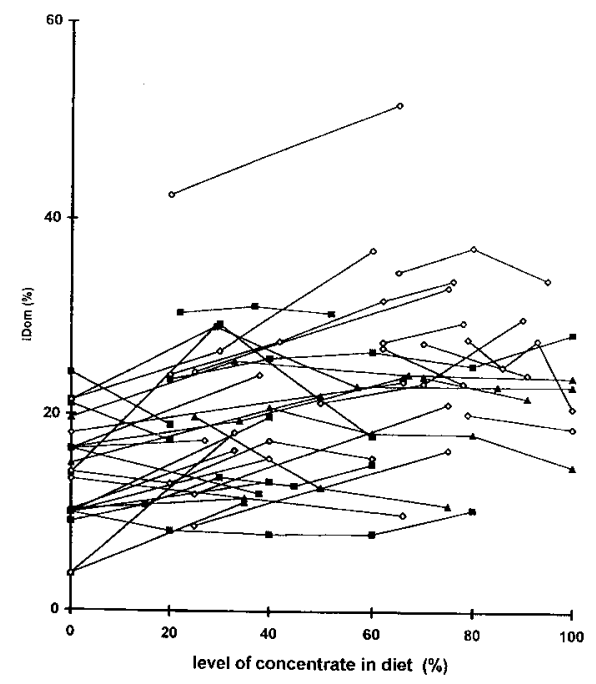

1c

Fig 1a, b, c, d. Effect of nature [rapidly degradable starch, $(\mathbf{A})$; slowly degradable starch, $(<>)$, digestible fiber ( $\boldsymbol{\square}$ ) and level of concentrate on total tract (TTDom), ruminal (RDom), intestinal (IDom) digestion of organic matter, and ruminal digestion of digestible organic matter (RDom)]. 


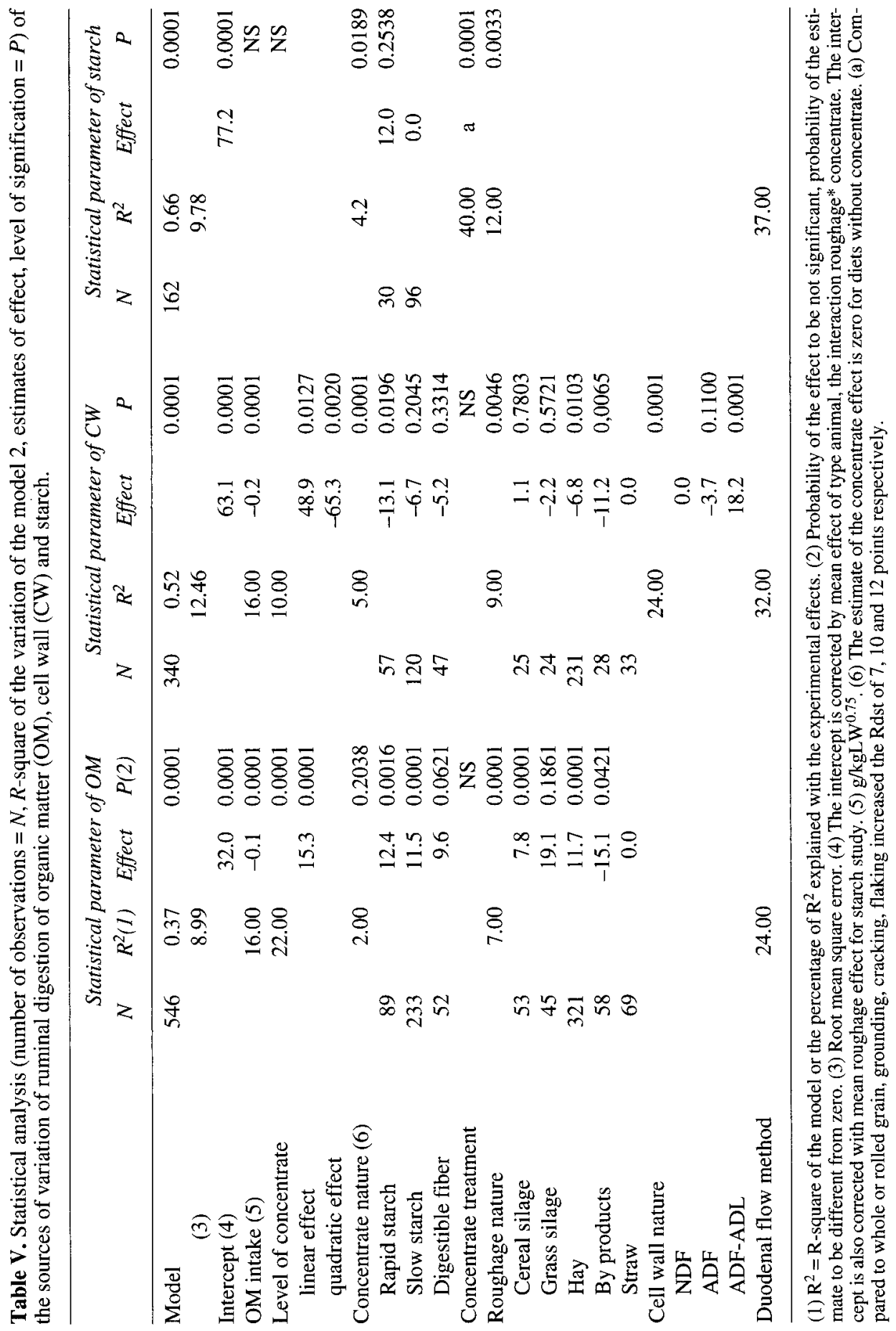


the roughage and the nature of the concentrate respectively explain $29 \%, 7 \%$ and $2 \%$ of the experimental source of variation. The level intake effect value is $30 \%$ higher in the rumen compared to the total digestive tract.

Figure $1 \mathrm{c}$ indicates that the intestinal $\mathrm{OM}$ digestion varies largely from one trial to another. There is a quadratic increase in the intestinal digestion of organic matter with the level of concentrate in the diet as indicated with the equation 1c (table III). There are large variations in the proportion of digestible organic matter digested in the rumen (fig 1d, equ $2 \mathrm{e}$ and $2 \mathrm{f}$ ).

\section{Total tract and rumen digestion of cell wall material}

This part of the data base contains 348 results from 113 trials. The mean values of the rumen (RDcw) and total tract digestibility of cell wall material (TTDcw) are presented in table II. Large variations in TTDcw were observed for the same concentrate level (fig 2a). The standard deviation of $\alpha_{i}$ $( \pm 11.39$ ) of model 1 confirmed the large variations in TTDcw between trials. Equation 2a (table III) illustrates a quadratic effect of concentrate level on TTDcw. The maximum value of TTDcw occurred with a level of about $40 \%$ concentrate in the diet. Model 2 showed that these variations can be largely explained ( $50 \%$ of the total variance) by the analytical cell wall criteria. The nature of the roughage or concentrate, explained about $10 \%$ of the total variation of TTDcw. Digestion was lower with straw and raw material. The concentrate decreases the TTDcw by about 3,8 and 11 points for DF, SS and RS, respectively.

The adjustments of the RDcw data (fig $2 \mathrm{~b}$ ) with model 1 produced equation $2 \mathrm{~b}$ (table III). As for TTDcw, there is a quadratic effect of concentrate level on $\mathrm{RDcw}$. The marginal influence of an increase in $\mathrm{C}$ is higher for $\mathrm{RDcw}$ than for
TTDcw, however, it decreases at a higher rate as shown by the value of the quadratic coefficients of C (20.9 vs 15.6). Consequently, the maximal RDcw was achieved with a lower incorporation of concentrate when compared to TTDcw ( $28 \%$ vs $40 \%$ ). The effect of the method used to measure the duodenal flow and the dietary factors (the nature of the concentrate and the roughage, level of intake) explain $32 \%$ and $40 \%$ of the experimental variations respectively (table V). The effect of the analytical nature of $\mathrm{CW}$ on its digestibility was equivalent for TTDcw and RDcw. The presence of RS, SS and DF in the diet decreased the RDcw. The intake level effect value is $20 \%$ higher in the rumen compared to the total digestive tract. The presence of RS, SS and DF in the diet decreased the RDcw by 12,9 and 3 points respectively. The intestinal digestibility of CW (IDcw) is generally low $(11.2 \pm 8.1 \%)$. For most of the trials with at least two levels of concentrate (fig 2b), there was initially an increase in intestinal CW digestibility with an increasing incorporation of concentrate. The equation $2 \mathrm{c}$ (table III) shows a quadratic increase of one point in IDcw for a $10 \%$ increase in concentrate level. Figure $2 d$ and equation $2 \mathrm{~d}$ illustrate the effect of the level of concentrate on ruminal digestion of digestible CW. CW material is mainly digested in the rumen $(80 \%)$. Intestinal digestion increases with the level of concentrate but remains inferior to $20 \%$ of the total digestible CW (when $\mathrm{C}=1$ ) whereas RDcw decreases by $30 \%$. The RDcw is $6 \%$ higher with cattle compared to small ruminant whereas no difference was observed between animal species for TTDW.

\section{Total tract and ruminal digestion of starch}

The mean values for starch digestion are presented in table II. The mean value for total tract digestion (TTDst) is 93.3 

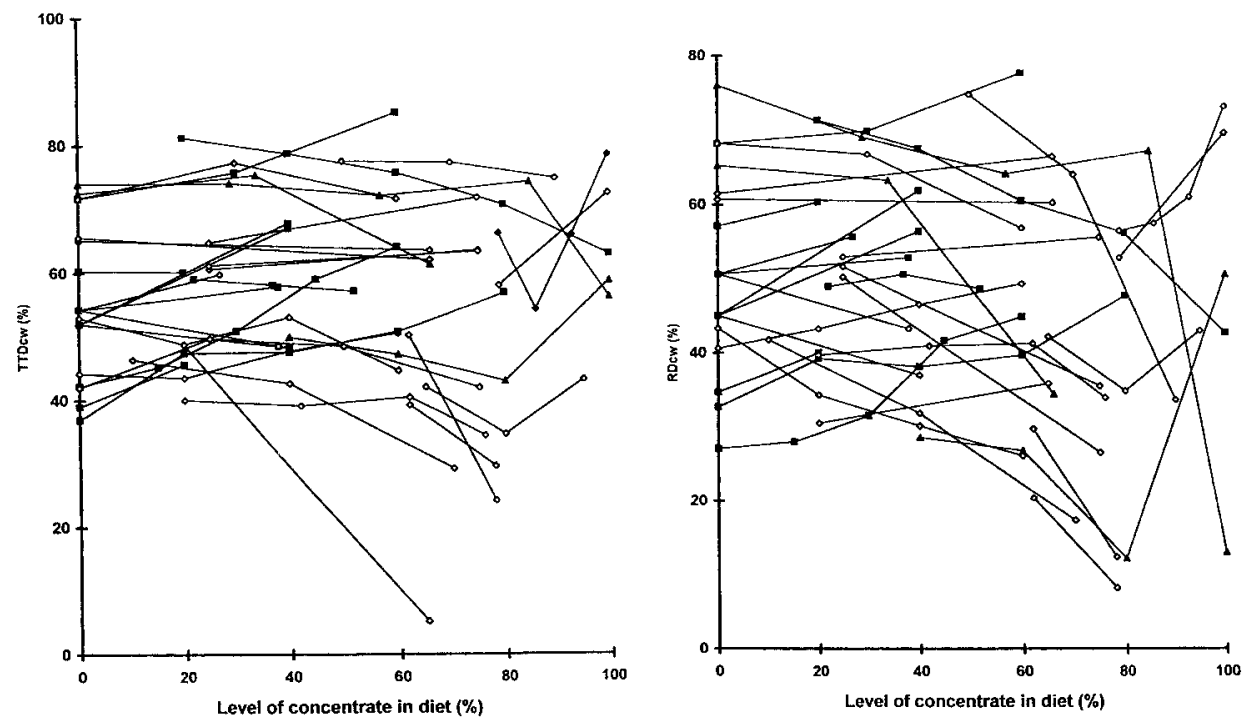

2a

$2 \mathbf{b}$

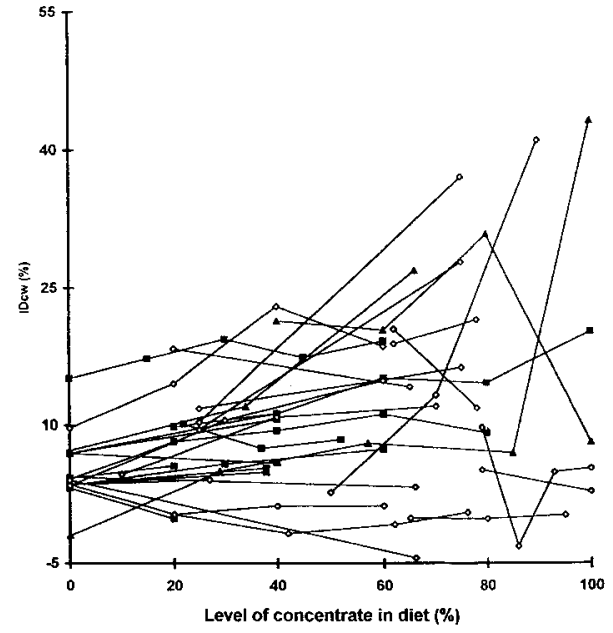

2c

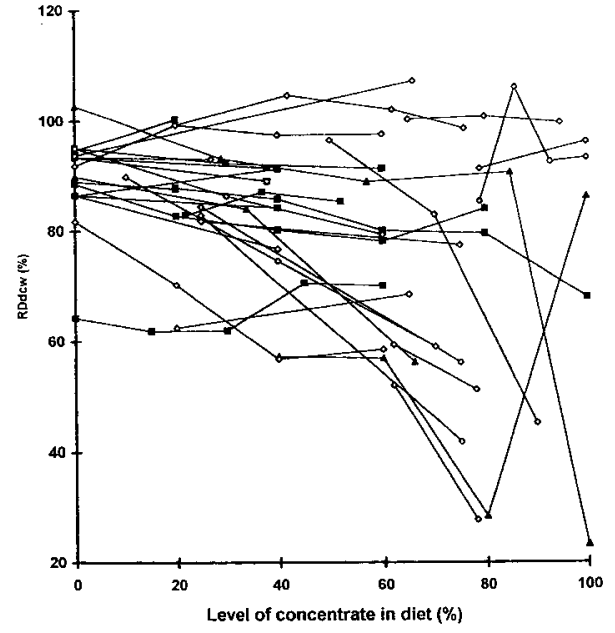

2d

Fig 2a, b, c, d. Effect of nature [rapidly degradable starch, (A); slowly degradable starch, $(<>)$, digestible fiber ( $\boldsymbol{\square}$ ) and level of concentrate on total tract (TTDcw), ruminal (RDcw), intestinal (IDcw) digestion of cell wall, and ruminal digestion of digestible cell wall (RDdcw)]. 
$( \pm 7.5 \%)$. No variation or only small variations in RD for starch (RDst) were observed with increasing levels of RS concentrate contrary to what is noticed with SS (fig 3a). The amount of ruminal digestion of starch increases with the level of concentrate (equ 3a, table III). The effect of the level of concentrate is the same when only SS concentrate is taken into account in equation $3 \mathrm{~b}$. The proportion of starch digested in the rumen increases with the level of concentrate (fig 3b, equ 3d, table III). As a consequence, the intestinal digestion of starch decreased with the level of concentrate (fig $3 c$, equ 3c, table III). Nevertheless, when SS concentrate only is taken into account in the equation, the effect of the concentrate level is not significant. Figure $3 \mathrm{~d}$ indicates that the intestinal digestion of starch increases when the ruminal digestion decreases.

Table V shows that the RDst of SS is $\mathbf{1 2}$ points lower than RS for which the mean RDst is $95.5( \pm 0.9 \%)$. Nevertheless, technological treatment was the first dietary factor in RDst variation (64\% of total variation). The method of duodenal flow determination explains $29 \%$ of the experimental variation. Compared to whole or rolled grain, treatment of cracking, grinding, flaking increased the RDst by 7,9 and 12 points. The ruminal digestion of digestible starch remained very high (90.9 $\pm 0.8 \%$ ) with RS while the contribution for SS was lower $(77.2 \pm 17 \%)$.

\section{Efficiency of microbial synthesis}

The efficiency of microbial synthesis (EMS) is $23.5( \pm 9.3) \mathrm{g} / \mathrm{kg}$ OM truly fermented in the rumen (OMF). Figure 4, based on trials with more than one level of concentrate, reveals that the EMS initially increases, then decreases with higher levels of concentrate. Statistical analysis of these data confirms these tendencies as indicated in equation $4 \mathrm{a}$ (table III). Maximum EMS occurs for a con- centrate level of about $40 \%$ of the diet. The SD value of the experimental effect $\left(\alpha_{i}\right)$, $7.88 \mathrm{~g}$, shows that for the same level of concentrate there are large variations in EMS. The level of concentrate was not significant with model 2 in contrast to model 1. Model 2 (table VI) indicates a significant effect of concentrate nature. EMS is lower ( -7 points) with RS compared to SS and DF.

\section{Microbial nitrogen flow}

The mean value of the microbial nitrogen duodenal flow is $1.10( \pm) \mathrm{g} / \mathrm{kg} \mathrm{LW}^{0.75}$. This value is equivalent to $55.06( \pm 16.65) \%$ of the duodenal nitrogen flow. The microbial duodenal flow first increases then decreases with the level of concentrate. The optimum is around $50 \%$ of concentrate (equ $4 \mathrm{~b}$, table III). There is a tendency for the microbial duodenal flow to be lower (table VI) with the concentrate RS compare to SS and DF.

\section{DISCUSSION AND CONCLUSIONS}

From a statistical point of view, this data base appears to be a non-orthogonal and an unbalanced design. This is usual in data analysis. The current objective was to quantify the main effects of the known qualitative and quantitative sources of variation.

Models of TTD analysis and prediction were systematically more accurate than those of $\mathrm{RD}$, thus revealing a large unexplainable variability in the measurements of the latter. This difference is likely to be the consequence of an inability of some methods to accurately measure duodenal flow, as already mentioned by Sutton (1977, 1979) and Owens and Hanson (1992). In the present study, marker methods were one of the main factors of variation in the regression models applied to RD. Because of possible interactions between methods and other factors, the biological analysis of these statistical variations is questionable. Never- 

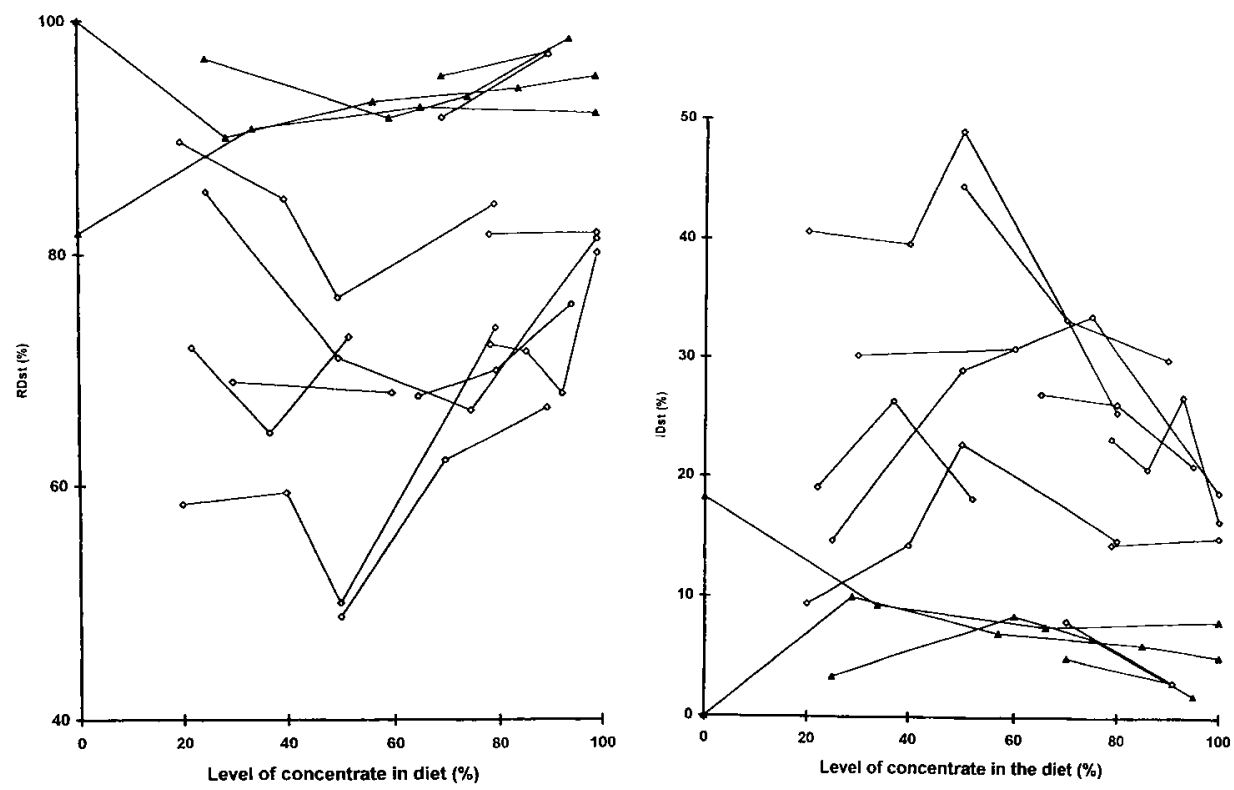

3a

3b
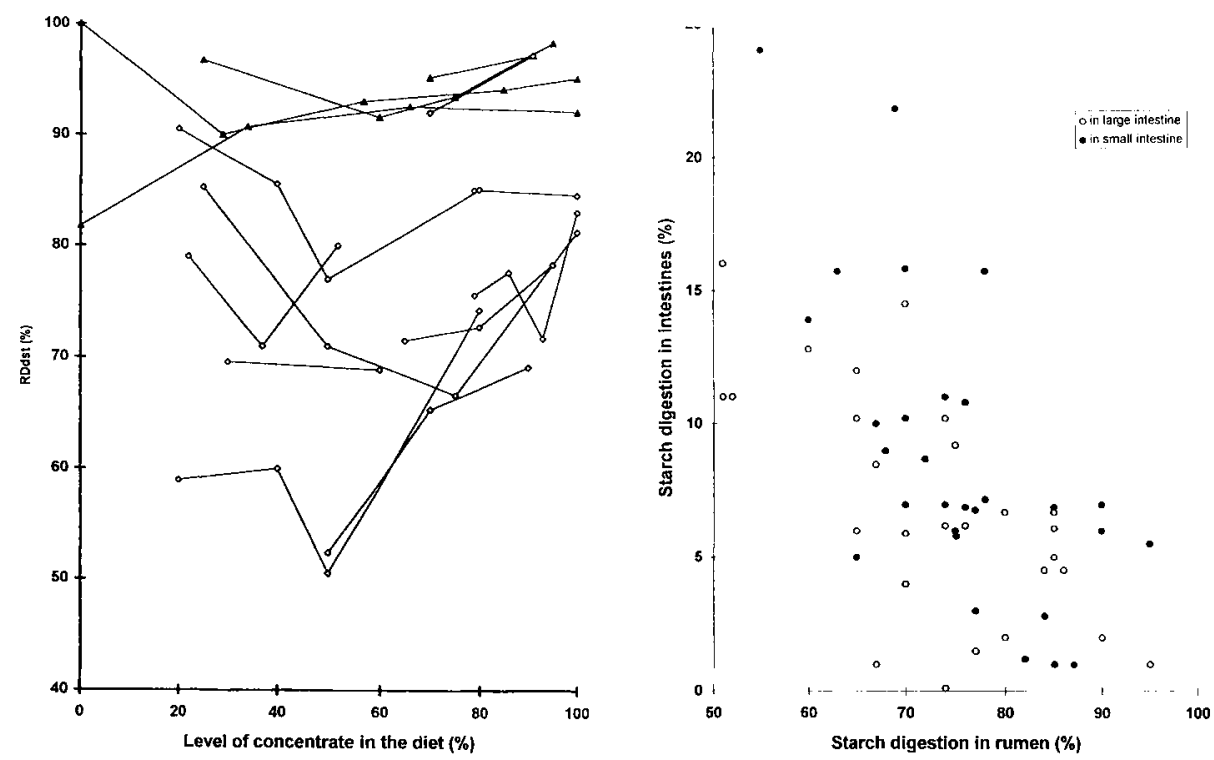

$3 c$

3d

Fig 3a, b, c, d. Effect of nature [rapidly degradable starch, ( $\mathbf{\Delta})$; slowly degradable starch, $(\mathbf{\square})$ and level of concentrate on ruminal (RDst), intestinal (IDst) digestion of starch, and ruminal digestion of digestible starch (RDdst)]. Variation of the partition of the starch digestion between the rumen and the intestines. 


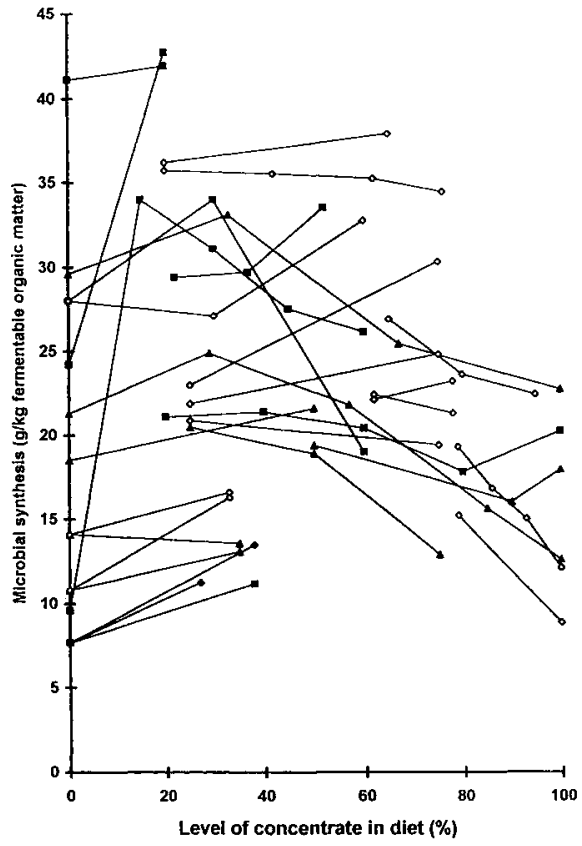

Fig 4. Effect of nature [rapidly degradable starch, $(\boldsymbol{\Delta})$; slowly degradable starch, $(<>)$, digestible fiber $(\square)$ and level of concentrate on the efficiency of microbial synthesis (EMS)].

theless the main effect of the method was used to correct the value of the mean (intercept in tables IV to VI). The different roughage types constitute a heterogenous class. A fresh grass category would have been interesting but it was not included in enough papers to create such a group. It appears that the hay group should be divided into legumes and grass but a preliminary statistical analysis rejected this hypothesis. Stage of growth of grass is an important factor of digestion variation that we did not take into account. The mean contribution of the stomachs to the total tract OM digestibilities was consistent with previous reviews (Armstrong and Beever, 1969; Armstrong and Smithard, 1979; Sutton, 1980). The current work shows however that this relative contribution varies widely $(\mathrm{cv}=$ $20 \%$ ). This result has some physiological consequences such as composition of the end-products of digestion and quantity of microbial nitrogen synthesized in the rumen. The large variations in TTDom between references were significant $(P<0.05)$, and could be only partly explained by classic main factors such as concentrate level, nature of concentrate and roughage, type of animal and level of OM intake. All these influences were confirmed, with a lower significance, for the RDom values. This result is probably due to our classification system which was not optimum. Nevertheless this factor reveals the existence of other large and biological variabilities (retention time in the digestive tract, etc) in TTDom and RDom.

Cell wall forms a heterogeneous fraction. The cellulose (ADF-ADL) which does not include lignin is much more digestible. The $\mathrm{CW}$ data analysis confirmed the major contribution of the reticulo-rumen towards $\mathrm{CW}$ digestion which is approximately $90 \%$ for most of the rations. This emphasizes the importance of maximizing the ruminal digestion of cell wall constituents. Moreover, the value of $0.9 *$ TTDcw can be used as a simple estimation of RDcw, at least for diets containing less than $50 \%$ concentrate. The increase of RDcw, between 0 and $28 \%$ of concentrate, may have several origins. It could be due to a better potential digestibility of $\mathrm{CW}$ for the concentrate. It is known however that $\mathrm{CW}$ potential digestibilities for some concentrates (barley, oats, etc) are lower than those of a good quality forage. The increase in CW digestibilities could also be obtained through improving the microbial activity when a moderate level of concentrate is used. It is likely that the decrease in RDcw for the higher level of concentrate results from digestive interactions (Michalet-Doreau and Sauvant, 1989; Berge and Dulphy, 1985, 1991). Such negative digestive interactions, are sometimes partially compensated (less than 14 points 
Table VI. Statistical analysis (number of observations $=n$, R-square of the variation of the model, 2 , estimates of effect, level of signification $=P$ ) of the sources of variation of the efficiency of microbial synthesis and the microbial duodenal flow.

\begin{tabular}{|c|c|c|c|c|c|c|c|c|}
\hline \multirow[t]{2}{*}{ Model } & \multicolumn{4}{|c|}{ Efficiency of microbial synthesis } & \multicolumn{4}{|c|}{ Nitrogen microbial duodenal flow } \\
\hline & $N$ & $R^{2}(1)$ & Effect & $P(2)$ & $N$ & $R^{2}$ & Effect & $P$ \\
\hline & 290 & 0.38 & & 0.0001 & 290 & 0.77 & & \\
\hline (3) & & 7.91 & & & & 0.35 & & \\
\hline Intercept (4) & & & 1.2 & 0.0010 & & & 1.0 & 0.044 \\
\hline OM intake (5) & & 7.00 & 0.07 & 0.0836 & & 79.0 & 0.02 & 0.0001 \\
\hline Level of concentrate & & & & $>0.5$ & & & & $>0.5$ \\
\hline Concentrate nature (6) & & 5.10 & & 0.099 & & 1.00 & & 0.200 \\
\hline Rapid starch & & & 16.5 & 0.040 & & & 0.5 & 0.120 \\
\hline Slow starch & & & 23.1 & & & & 0.9 & \\
\hline Digestible fiber & & & 23.1 & & & & 0.9 & 0.007 \\
\hline Roughage nature & & & & $>0.5$ & & & & $>0.5$ \\
\hline Duodenal flow method & & 29.0 & & & & 4.70 & & \\
\hline
\end{tabular}

(1) $R^{2}=R$-square of the model or the percentage of $R^{2}$ explained with the experimental effects. (2) Probability of the effect to be not significant, probability of the estimate to be different from zero. (3) Root mean square error of the mean. (4) The intercept is corrected by mean effect of the interaction roughage* concentrate, method

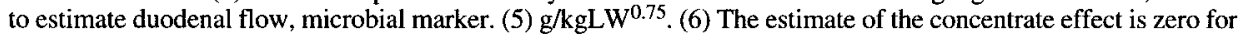
diets without concentrate.

in this study) in the distal part of the gut. Such a substitute role of the hindgut has already been observed by Ullyatt et al (1975) for poor quality forages. Our results suggest that the substitute role is higher with small ruminants than with cattle. The influence of the nature of concentrate is highly significant for TTDcw and RDcw values. The depressive action of RS is higher than SS or DF probably because of ruminal acidity. The negative influence of the intake level on TTDcw and RDcw, as on TTDom and RDom, has already been mentioned by Blaxter et al (1956), Demarquilly and Andrieu (1987).

This data base confirms the large differences in ruminal starch digestibility (Sauvant et al 1994; Orskov 1986; Waldo 1973). The nature of the starch (RS vs SS) on one hand, and the technological treatment on the other hand, are the main factors of variation
(Theurer, 1986; Rooney and Pflugfelder, 1986; Orskov, 1979). Moreover, this study indicates a positive relationship between the level of starch in the diets and the ruminal amylolytic capacity. Nevertheless, low ruminal digestion levels for starch are compensated in the intestines.

The values of EMS had the same variation range as the one indicated by Vérité et al (1986), Demeyer and Van Nevel (1986) and Durand (1989). The quadratic response of EMS according to the concentrate level was first noticed by Chamberlain and Thomas (1979) and Mathers and Miller (1981). Ramangasoavina and Sauvant (1993) first proposed a quadratic equation based on 49 values and 14 experiments carried out in dairy cows. An optimum EMS around $40 \%$ should indicate a balance between the growth potential and energy availabilities. The positive influence of 
intake level on EMS has already been indicated by Vérité et al (1986). This was consistent with the positive relationship observed between EMS and the liquid outflow rate observed by Van Nevel and Demeyer (1979). With a data base concerning only dairy cows, Ramangasoavina and Sauvant (1993) observed a mean increase in EMS of $0.97 \mathrm{gNm} / \mathrm{kg} \mathrm{OMF} / \mathrm{kg}$ of dry matter increase. Taking into account body size effect, the value that we found, $0.09 \mathrm{~g} \mathrm{Nm} / \mathrm{kg} \mathrm{OMF} / \mathrm{g} \mathrm{OMI} / \mathrm{kg} \mathrm{LW}^{0.75}$, is consistent with the previous results. This effect of intake was the result of its positive influence on Nm flow (table VI) and its negative effect on RDom (table V). In contrast with the observations of Vérité et al (1986), there was no significant influence of the nature of the forage on EMS. Probably the different forage groups formed were too heterogeneous. To our knowledge, the influence of the type of concentrate on EMS had not, until recently, been supported by a literature data base. Hoover and Stokes (1991) indicated that the rate of carbohydrate digestion is the major factor controlling the energy available for microbial growth. The results of this study underline that rapidly degradable carbohydrates lead to the lowest EMS. There is probably an energetic uncoupling in microbial requirements and availabilities. Moreover, the nature of the diet which alters the composition of the microbial biomass (adhered bacteria, cellulolytic, amylolytic, etc) may partly explain the variation in EMS (Yang, 1991; Broderick and Merchen, 1992).

From this study, it can be concluded that the nature of the concentrate has a significant effect on digestion. Compared to DF and SS, RS results, in the lowest efficiency, of the microbial synthesis and, in the highest depression, of cellulolysis in mixed diets. Moreover, the optimum efficiency of the rumen microbial population is reached with 30 to $40 \%$ of concentrate level in the diet. The digestion rate for starch varies with the level of concentrate.

\section{REFERENCES}

Archimède H (1992) Étude des facteurs impliqués dans les interactions digestives entre les fourrages et les aliments concentrés chez les ruminants. Thesis, Inst Nat Agron Paris-Grignon, France

Armstrong DG, Beever DE (1969) Post abomasal digestion of carbohydrate in the adult ruminant. Proc Nutr Soc 28, 121-132

Armstrong DE, Smithard RR (1979) The fate of carbohydrate in the small and large intestines of the ruminant. Proc Nutr Soc 38, 283-294

Berge P, Dulphy JP (1985) Etude des interactions entre fourrage et aliment concentré chez le mouton. Facteurs de variation du taux de substitution. Ann Zootech 34, 313-334

Berge P, Dulphy JP (1991) Etude des interactions entre fourrage et aliment concentré chez le mouton. II. Facteurs de variation de la digestibilité. Ann Zootech $40,227-246$

Blaxter KL, Graham Mc C, Wainman FW (1956) Some observations on the digestibility of food by sheep, and on related problem. Br J Nutr 10, 69-91

Broderick GA, Merchen NR (1992) Markers for quantifying microbial protein synthesis in the rumen. $J$ Dairy Sci 75, 2618-2632

Chamberlain DG, Thomas PC (1979) Ruminal nitrogen metabolism and the passage of amino acids to the duodenum in sheep receiving diets containing hays and concentrates in various proportions. J Sci Food Agric 30, 677-686

Demarquilly C, Andrieu J (1987) Digestibilité et ingestibilité des fourrages verts chez le mouton : effets respectifs du niveau d'alimentation et de l'âge ou du poids des animaux. Reprod Nutr Dev 27 (1 B), 281-282

Demeyer D, Van Nevel C (1986) Influence of substrate and microbial interaction on efficiency of rumen microbial growth. Reprod Nutr Dev 26, 161179

Durand M (1989) Microbial protein synthesis in the rumen. Atti XXIII Simposio Internazionale di Zootecnia, Ed Greppi GF, Corti M, 38-71

Hoover WH, Stokes SR (1992) Balancing carbohydrates and proteins for optimum rumen microbial yield. J Dairy Sci 74, 3630-3644

Mathers JC, Miller EL (1981) Quantitative studies of food protein degradation and energetic efficiency of microbial protein synthesis in the rumen of sheep given chopped luceme and rolled barley. Br J Nutr $45,587-604$

Michalet-Doreau B, Sauvant D (1989) Influence de la nature du concentré, céréales ou pulpe de betterave, sur la digestion chez les ruminants. Inra Prod Anim 2, 235-244

Nocek JE, Tamminga S (1991) Site of digestion of starch in the gastrointestinal tract of dairy cows 
and its effect on milk yield and composition. $J$ Dairy Sci 74, 3598-3629

Orskov ER (1979) Recent information on processing of grain for ruminants. Livest Prod Sci 6, 335-347

Orskov ER (1986) Starch digestion and utilization in ruminants. J Anim Sci 63, 1624-1633

Owens FN, Hanson CF (1992) Symposium: external and internal markers for appraising site and extent of digestion in ruminants. $J$ Dairy $S c i 75,2605$ 2617

Ramangasoavina B, Sauvant D (1993) Validation comparée de trois modèles de digestion ruminale pour prédire les flux azotés duodénaux microbiens. Ann Zootech 42, 164-165

Rooney LW, Pflugfelder RL (1986) Factors affecting starch digestibility with special emphasis on sorghum and corn. J Anim Sci 63, 1607-1629

SAS institute Inc (1988) User's Guide: Statistics, Cary, NC, USA

Sauvant D, Chapoutot P, Archimède H (1994) La digestion des amidons par les ruminants et ses conséquences. Inra Prod Anim 2, 115-124

Sutton JD (1977) Feed evaluation by measurement of sites of digestion in cannulated ruminants. Proc Nutr Soc 36, 203-209

Sutton JD (1979) Carbohydrate fermentation in the rumen, variation on a theme. Proc Nutr Soc 38 , 275-281
Sutton JD (1980) Digestion and end-product formation in the rumen from production rations. In: Digestive physiology and metabolism in ruminants (Y Ruckebuch and P Thivend eds). MTP Press, Lancaster, UK, 271-308

Theurer CB (1986) Grain processing effects on starch utilization by ruminants. J Anim Sci 63, 1649-1662

Ullyatt MJ, Dellow DW, Reid CSW, Bauchop T (1975) Structure and function of the large intestine of ruminants. In: Digestion and metabolism in the ruminant (YW McDonald and ACI Warner eds). Univ of New England Publishing Unit, Armidale, Australia, 119-133

Van Nevel C, Demeyer D (1979) Stoichoimetry of carbohydrate fermentation and microbial growth efficiency in a continuous culture of mixed rumen bacteria. Eur J Appl Microbiol Biotechnol 7, 111-120

Vérité R, Durand M, Jouany JP (1986) Influence des facteurs alimentaires sur la protéosynthèse microbienne dans le rumen. Reprod Nutr Dev 26, 181-201

Waldo DR (1973) Extent and partition of cereal grain starch digestion in ruminants. J Anim Sci 37, 1062 1074

Yang WZ (1991) Étude cinétique de la colonisation microbienne des aliments dans le rumen du mouton. Conséquences sur la compartimentation de la biomasse et sur sa dynamique de sortie du rumen dans le cas de différents types de rations. Thèse, université de Clermont-Ferrand II, France, $n^{\circ} 307$ 